\title{
Dealing with a resurgent Russia: Engagement and deterrence in US international broadcasting, 2013-2019
}

\author{
N. A. Tsvetkova \\ St. Petersburg State University, \\ 7-9, Universitetskaya nab., St. Petersburg, 199034, Russian Federation
}

For citation: Tsvetkova N.A. Dealing with a resurgent Russia: Engagement and deterrence in US international broadcasting, 2013-2019. Vestnik of Saint Petersburg University. International Relations, 2019, vol. 12, issue 4, pp. 435-449. https://doi.org/10.21638/11701/spbu06.2019.403

\begin{abstract}
Among the numerous discussions of US international broadcasting, the regional dimension in terms of American projects in Russia and its neighboring states are rarely given explicit consideration. The paper reviews the strategies, projects, and their results in connection with US international broadcasting towards Russia and, more broadly, towards Eastern Europe and the post-Soviet space. The first section reviews the shifts in US international broadcasting during the period of 2013-2016, when the administration of Barack Obama introduced new strategies and projects to engage the Russian audience through US international media. The second section demonstrates how the sanctions imposed against Moscow and investigations about the possible Russian impact on elections in both United States and Europe have modified international broadcasting in terms of introducing a new deterrence policy during the period of 2017-2019. The paper concludes that the United States has gained some success in reaching the Russian-speaking populations through international broadcasting and, moreover, its datadriven digital diplomacy has brought some results in containing Russia's informational activities in Eastern Europe, Balkan region, and post-Soviet countries. While the administration of Barack Obama conducted the policy of engagement towards the Russian-speaking world, the first administration of Donald Trump is pursing the policy of deterrence.
\end{abstract}

Keywords: public diplomacy, United States, Russia, sanctions, Eastern Europe, international broadcasting, big data, digital diplomacy, data-driven diplomacy.

\section{Introduction}

US international broadcasting embraces an array of activities via traditional networks and digital space to engage people worldwide and support national objectives of foreign policy. US international broadcasting advances US national interests and values of American society by providing audiences with consistently accurate content and is comprised among others such networks as Voice of America (VOA), Radio Free Europe/Radio Liberty (RFE/RL) [1]. The international broadcasting has always responded to regional or global threats. Historically, the threat to American values coming from the German projects in the field of information and education in the Western Hemisphere during the period of 1930s served as a trigger for making and disseminating a series of documentaries and animated movies in order to attract the audience in all the Latin America countries. The US participation in World War II led to the expansion of an informational component of the public diplomacy. The VOA was set allowing the government to talk about American

(C) Санкт-Петербургский государственный университет, 2019 
people, values, and democracy in a wide variety of countries. The cultural and ideological confrontation with Moscow during the Cold War shaped the effective international broadcasting, stimulated a generous funding from the US budget, and shifted the international broadcasting into a global project to protect American values, lifestyles, and culture. The VOA and REF/RL were turned out to be the most effective instrument to undermine the ideology of the communism and disparage the Soviet Union's policy around the world. The events of the September 11, 2001, enhanced the development of new approaches to the US international broadcasting. The public diplomacy became much more politicized with its projects to promote democracy aimed mostly at leaders of pro-liberal parties and the opposition activists in the Middle East. A range of short-term informational campaigns, political advocacy became the priority. Alhurra TV, Radio Sawa and Radio Farda were introduced to win the Arab audience with the ideas of democracy and liberal world. The propaganda in social media by various political groups and authoritarian states, as well as the wide exploitation of the internet in a political life have had an impact on the US digital diplomacy and pushed the advent of big data, data diplomacy, and, finally, artificial intelligence into the kingdom of the international broadcasting. The unexpected rising of Russia's informational and digital activities has become a new challenge for the United States since 2013. Russia's aggressive promotion of traditional values, anti-Americanism, and antiliberal stance are viewed as a new threat for American values and its foreign policy.

The purpose of this study is to reveal the new trends in the US international broadcasting determined by Russia during the period 2013-2019. The year of 2013 witnessed the beginnings of a new shift in the US international broadcasting driven by Russian informational activity around the world, and the year of 2019 has been selected for the research as much as the first outcomes in the US international broadcasting are visible and can be discussed.

The methodology of the study is based on elements of the theory of realism and constructivism. The theory of the realism allows to draw conclusions about the importance of national interests and security while the policy of international broadcasting is elaborated and conducted, and the theory of constructivism allows to illustrate how the perceptions of Russia shape the decision-making in the public diplomacy. The primary sources for the research are the documents of the US government including the bills and hearings at the US Congress and some reports taken from the agencies which implement some projects in the field. These documents are analyzed by the methods of historical and discourse analyses to reconstruct both perceptions of Russia among the political establishment of the United States and the goals of the international broadcasting in the terms of national security issues and the policy towards Russia.

Before our analysis, we have to mention that despite a wide interest to the US international broadcasting and public diplomacy among scholars and experts, the question of the US international broadcasting towards Russia, Europe, and post-Soviet space has been underestimated by scholars. Most of works discusses the general problems referred to American soft power illustrating some historical and current insights. The Russia as a target country in the US international broadcasting is mainly mentioned in numerous books on the cultural Cold War. The period of the post-Cold War and, the periods of Barack Obama and Donald Trump administrations in particular, have still been beyond the scholarship [2]. 
The article consists of two sections. The first section discusses the problems of the US international broadcasting from 2013 to 2016, and the second section reviews the foreign policy challenges that stimulated a new wave of transformations and shifts in the international broadcasting since 2017 and up to the events in 2019.

\section{Engaging the Neglected Russians, 2013-2016}

Russia's international broadcasting and digital diplomacy turned out to have been the core challenge for the US public diplomacy [3]. Some American experts argued that in the context of a reduction in funding for Russian-language broadcasting, Moscow was the main source of news in Russian for a global audience. Roughly, 90 percent of information disseminated in Russian language around the world came from Russia, and the news, facts, and interpretations were said to be controlled by the Kremlin [4]. In addition, some reports stated that Russia spent about \$1.4 billion per year on the Russia Today channel, and its audience reached 600 million viewers weekly including all traditional and digital platforms that, in contrast, one and a half times more than the audience of all the American international broadcasting channels that encompassed 345 million views weekly and $\$ 780$ million per year [5].

Contrary to the Russia's active international informational projects, the US international broadcasting in Russia, East Europe, and post-Soviet space was quietly fading. Management failures, reduced funding and the lack of clear strategies of how to attract the Russian-speaking population in the countries of the former socialist camp in Europe and the USSR had weakened the American public diplomacy. American broadcasting channels had lost a target audience that became grasped and influenced by the Russian channels. In Moscow, The RFE/RL, which played a significant and effective role in US informational policy during the Cold War, reduced its staff and traditional FM radio broadcasts hoping to switch to the digital broadcasting. However, the implementation of the digital strategy failed due to a lack of financial resources in 2013. A managing editor was not formally appointed for a long time that made the functionality of the radio station be very frail and allowed some employees to misuse the federal funding sources. The VOA broadcasting in Russian language had also many administrative flaws related to contracts, cash transactions, and property management. Since 2008, The VOA in Russia has had six chief editors that created uncertainty and lowered staff optimism. Moreover, the emphasis of the American public diplomacy on the Middle East has had significantly hindered the funding for the projects in Russia and Europe as a whole. Russia has moved to the position of a low-priority country in the international broadcasting and public diplomacy since 2001. Finally, some restrictions exposed by the Russian government on American foundations, agencies, and projects relative to the public diplomacy and evaluated by Moscow as the tools for interference in a political life contributed to the fading of the dissemination of American values through the broadcasting. Consequently, in 2013, the American broadcasters reached 0.1-0.3 percent of the audience (from 143,000 to 430,000 people) throughout Russia that was an unprecedented failure in the US public diplomacy [6].

The returning of Crimea became another important premise for the crucial revision of the US public diplomacy. This event was designated in the United States as "the most amazing information warfare blitzkrieg we have ever seen" [7]. Moscow and its new informational policy was perceived as a new threat for the interests of the United States. Wash- 
ington was confronted with the fact that a significant part of Russian-speaking population around the world were removed from American influence and were under the influence of Moscow's interpretations of the political course. The American establishment acknowledged as a mistake that since end of the Cold War, Washington has regarded its position in Russian-American relations as a complete victorious power and thus has not made necessary efforts to maintain its engagement with the people who could might consume American message in Russian language. Russia's soft power policy and broadcasting were called as a propaganda machine, and the methods applied by the Kremlin were designated as "weaponization of information - news and analysis as a means of provoking strong negative emotions, potentially leading to hatred, incitement and, ultimately, the justification of violence" [8]. Russian propaganda was reported to create an alternative reality in a media-controlled space that posed a threat to democratic values. These perceptions became strong imperative to a new policy of international broadcasting.

Without delay, the Russian-speaking population located in post-Soviet territory, and in the countries of East Europe in particularly, was announced as a priority in the policy of international broadcasting. The laws passed the US Congress with unprecedented speed allocated additional millions for the support of non-governmental organizations, activists, internet freedom, and informational campaigns in Russia and in neighboring countries until 2018. For the first time since the end of the Cold War, the laws have forbidden to engage the representatives of the Russian government in the projects of the public diplomacy. Political activists, oppositional groups, journalists, and bloggers have been defined as a target group for the public diplomacy $[9 ; 10]$.

During the period of 2014-2016, the Obama administration reinvigorated the VOA and RFE/RL and returned them to the field of new of US - Russian competition for the minds and hearts of people living in the countries neighboring Russia. The additional appropriations allowed to renew 35 programs in Russian for the audience in post-Soviet space. More than seventeen new languages have been introduced in the US broadcasting and among them, the language of the Crimean Tatars, a minority ethnic group in Crimea [11].

To reach people in Russia, the online channel known as Current Time TV was established in October, 2014. The channel has become a pillar of the US broadcasting for those Russians who want tune into alternative interpretations of official news watched on state-controlled TV. The channel has been entirely focused on the Russian-speaking population and contributed enormously to the fact-checking strategy of the US broadcasting. Almost all the "facts" distributed by the Russian television is checked and denied or confirmed by the Current Time. This popular strategy attracted public in the former Soviet republics - Azerbaijan, Belarus, Estonia, Georgia, Latvia, Lithuania, Moldova and Ukraine - who collaborated with the Current Time. The channel united 30 media outlets in these countries evaluated as the vulnerable to the Russian news. Soon, the audience of three American channels, namely the VOA, RFE/RL, and the Current Time, reached $4.9 \%$ population in Russian in 2016, and it was a success of the US public diplomacy [12;13].

At the same time, the reorganization of the agencies responsible for the public diplomacy, international broadcasting, and digital diplomacy were underway. The Board of Broadcasting Governors established in 1994 as a product of the post-Cold War epoch with the independent status from the official foreign policy aims ceased to exist, and the area of international broadcasting received a new agency and new rules of operation. The 
US Agency for Global Media (further, USAGM) that reports directly to the President and Secretary of State, is required to disseminate information consistent with the US official foreign policy. Earlier, according to the law of 1994 the broadcasters had to disseminate the objective information relative to the United States and the target region or country. The law on international broadcasting in 1994 was eliminated in December 2016, when the president signed a new act on international broadcasting being absolutely ensured that the new president would be Hillary Clinton, and the direct subordination of the broadcasters to the interests of the US foreign policy like it was during the Cold War would be a benefit for winning the audience with liberal discourse [14]. The unexpected victory of Donald Trump played a trick with international broadcasting and public diplomacy: The President has received the power to impact directly the content of channels, appoint loyal executives, and reduce the funding. In early of 2017, this law and the intentions of the President to cut the staff in the departments of the public affairs created additional problems for the US international broadcasting, digital diplomacy, and public diplomacy as a whole.

Summing up, we can state that the Russia's foreign policy and its wide-scoped informational activities in both traditional and digital platforms that reached millions of people around the world has pushed the revisions of the US international broadcasting during the administration of B. Obama. The president and his experts were able to revive the broadcasters to reach the Russian-speaking audience and to reestablish the agencies dealing with the international broadcasting.

\section{Deterrence of Russian Malign Influence, 2017-2019}

Through the history of public diplomacy, the American government and the executive branch in particular, has been in favor of the development of this informational component in foreign policy. The US President has been the main advocate of projects and funding for public diplomacy. For example, President Woodrow Wilson created the well-known the US Committee on Public Information that spread a positive image of the United States in various countries including Russia. President Harry Truman initiated the first global exchange program, and President Dwight Eisenhower convinced the Hill to fund the US Information Agency, a legendary community of practitioners who defeated the Soviet informational campaigns. As a rule, the US Congress, with some exceptions, was a more conservative and less responsive in terms of the funding and the expansion of the international broadcasting and often did not support the White House initiatives reducing the financial budget.

The current administration of Donald Trump is an unusual phenomenon and a challenge to the international broadcasting of the United States. The President denies the need for generous funding of various programs in the field. There are still problems with appointments to posts at the Department of State and embassies in the field of both international broadcasting and public diplomacy as a whole. President D. Trump and his first Secretary of State Rex Tillerson did not perceive the public diplomacy as a significant foreign policy instrument. The Secretary of State articulated the intentions of his president to reduce funding for the offices at the Department of State, BBG, and even such crucial agency as the Global Engagement Center set by Barack Obama to deal with the propaganda of ISIS. The President Trump did not appoint a new chief for public diplomacy 
until December 2017 and also did not to update the staff in the field of the international broadcasting apparatus that traditionally is carried out by each newly elected president. After the departure of the democratic administration, some staff and diplomats left their positions in the bureaus on the public diplomacy at the Department of State, but some of them continued working that in many cases contributed to the survival of the public diplomacy. Until the end of 2017, the public diplomacy apparatus was in the hands of the appointee of the democratic administration. In December of 2017, the President Trump finally approved the new head of the department, but his career ended very quickly as much as he failed to fit into the framework of behavior outlined by the president. Then, the public diplomacy was governed by the presswoman $\mathrm{H}$. Nauert but she also left the post in October 2018. Today, many positions are vacant and the problem with the leadership remains crucial, but not too important due to the fact that the most of the projects funded by the Congress are realized by the community of those American experts and diplomats who are eager to keep the international broadcasting as an effective instrument in the new reality of the digitalization of the world politics, cybersecurity, and social media openness to any propaganda.

The president's personal digital activity is another major challenge for the international broadcasting. Personalization of politics, emotions, the transfer of decision-making process to the digital space, the breaking of the media mainstream and his critics of liberal media have still made an important problem for the US informational projects. What kinds of values must be broadcasted to a foreign audience? Values of the president? How must the personality of the president be depictured for the audience? The international broadcasting has never had such a dilemma as a clash of American liberal values traditionally promoted by the US international broadcasting with the personality of the current president, who promotes some contradictory values. In order to deal with this problem, the experts in international broadcasting have reduced the number of informational flows about the president not to be in a situation when the official US international broadcasting criticizes the president.

However, such the unfriendly attitude of the president towards the international broadcasting has become an incentive for the community of American experts, diplomats, and former grantees to promote the public diplomacy. The US Congress, contrary to the will and desire of the president, annually increases funding for the project in the field of international broadcasting, and employees and experts in this field who have not left government posts are involved in the renewal of the international networks to be suited for the digital world. Moreover, the wide and profound perception of Russia as a threat to the United States and Europe is proved to be a political impact for the new wave of developments in the public diplomacy. In 2017, the Congress, not the White House, raised the question on the necessity to increase the funding for the international broadcasting. Instead of $\$ 667$ million requested by the White House the for international broadcasting programs, the Congress allocated $\$ 780$ million [15].

By early 2018, after the US Congress had discussed the possible interference of Russia in the elections in the United States and Europe within the numerous hearings, the public diplomacy discourse towards Moscow began changing again [4]. Instead of the previous statements about the necessity on winning Russian-speaking population and the Kremlin propaganda, the discourse on Russian malign influence began dominating in governmental documents, mass-media, and in reports of American experts. They claimed that Russia 
has conducted at least 362 informational and malign operations targeting 41 European countries since 2000 [16]. The investigations of the possible interference of Russia in the 2016 presidential elections in the United States and the findings submitted by the Google, Twitter, Facebook, and YouTube corporations to the public have modified the imperative of the international broadcasting. Such information that Russia created up to 470 Facebook pages for American citizens and they were seen by 126 million Americans, with 29 million users engaging in some action with the posts, notably sharing, liking, or writing a comment has transformed the discourse on the winning the hearts and minds in Russia by the discourse on the deterrence of Russian soft power [4].

The discourse on the malign influence became a new foundation for the US international broadcasting and was defined as "the coordinated, integrated, and synchronized application of national diplomatic, informational, military, economic, business, corruption, educational, and other capabilities by hostile foreign powers to foster attitudes, behaviors, decisions, or outcomes within the United States" [17]. Russia has been depictured in the documents as the country that posed threats including influence operations targeting America and the Western world. Hence, the budget relative to the international broadcasting prioritized the policy of countering Russian malign influence in Europe and Eurasia since 2018 [18]. The countries of East Europe and Eurasia were named as the most vulnerable and thus be supported through the projects of the international broadcasting and public diplomacy.

Consequently, for the first time since the end Cold War, the US government has created a special area in the international broadcasting to conduct the counter-propaganda against Russia in the countries of East Europe. The informational deterrence of Russia was intertwined with the sanctions imposed on Moscow. The international broadcasting and public diplomacy has strongly been connected for the first time to the sanctions' policy and lost its soft essence to build bridges and develop a cooperation, but not to destroy the people-to-people relations. The famous law on the sanctions - Countering America's Adversaries Through Sanctions Act - allocated \$250 million for a project called as the Countering Russian Influence Fund in Europe for 2018 and 2019 in order to contain the information coming from Russia. For 2020, the figure of \$275-280 million has being discussed among the experts' community $[19 ; 20]$.

The projects in the field of the building of democratic structures and credible elections in Europe and Eurasia, including Russia, grew significantly and became prioritized in the public diplomacy up to the mid-2019. The appropriations acts dealing with the foreign policy designates that "funds are available to support democracy programs in the Russian Federation, including to promote Internet freedom and rule of law strategy" [15]. The term "democracy programs" is defined as "programs that support good governance, credible and competitive elections, freedom of expression, association, assembly, and religion, human rights, labor rights, independent media, and the rule of law, and that otherwise strengthen the capacity of democratic political parties, governments, nongovernmental organizations and institutions, and citizens to support the development of democratic states and institutions that are responsive and accountable to citizens" [15].

The key agencies for implementing the new strategy is the Human Rights and Democracy Fund of the Bureau of Democracy, Human Rights, and Labor at the Department of State, the National Endowment for Democracy and other organizations subordinated to the Foggy Bottom. These organizations can retrieve some funds from the additional 
budget allocated by three separate funds as $\$ 157.7$ million, $\$ 89,6$ million and $\$ 69.5$ million available until September, 2020, in order to implement special and additional programs to protect democracy in Europe and in Russia itself. A separate fund is appropriated to in the traditional public diplomacy and democracy programs as the Freedom Support Act 1992 and the Support for Eastern European Democracy Act of 1989. The programs received $\$ 760,334,000$, until September, 2020, and they have also been increased [20].

Other important component of the new policy is the protection of civil society activists and journalists. This policy has been actively used since the second administration of Barack Obama. Governmental and non-governmental organizations have been created to help the opposition in Russia and other countries. An amount of $\$ 15$ million is allocated on supporting and protecting civil society activists and journalists who have been threatened, harassed or attacked. Moreover, such a new direction in public diplomacy as forensic anthropological assistance related to the exhumation and identification of victims of war crimes, crimes against humanity and genocide has been funded by $\$ 10$ million [20].

Finally, the US agency for International Development, a traditional agency responsible for promoting democracy, credible elections, and supporting of non-governmental organizations around the world are reported to have spent about 1.3-1.5 billion dollars for democracy and public diplomacy in Europe and Eurasia since 2018. The projects deal with the support of independent media in Europe, Eurasia and Central Asia to increase their resilience to pressure and misinformation coming from Russia. Financing in the media space consists of following main activities: media literacy, increased access to objective information, capacity building and strategic communications [21].

The sanctions against Russia and the enlarged funding have contributed to significantly upgrading and reviving the international broadcasting in terms of huge support of the USAGM. This agency received an unprecedented amount of $\$ 804$ million to develop programming of the channels dealing with Europe and Russia in 2019 [1]. The VOA and RFE/RL were tuned into digital platforms, Internet television, and even into financial sources for arranging of various seminars for citizens from Eastern Europe and Eurasia including Russia. The target audience of these channels has significantly increased through the expansion of content for young people.

The additional funding for the new data-driven methods in analyzing the target audience and shaping a message has helped the USAGM to reach a weekly audience of 345 million people across radio, television, and the internet. The RFE/RL websites were visited by 508 million times representing a 15 percent increase from the year of 2017. The number of video views across YouTube doubled in 2018 when compared to 2017 reaching more than 1.0 billion views [1].

The cementing of the of informational deterrence along with the perimeter of Russia became the main tactics of the US international broadcasting during the period of 2018-2019. The countries of the Balkan Peninsula and East Europe where Russia tries to increase its influence are said to be a priority in this new policy. B 2018, a newswire for the Balkans was established. RFE/RL's Balkan Service is reported to engage the vibrant but very often not friendly populations in Bosnia, Serbia, Montenegro, Macedonia, and Kosovo. The RFE/RL relaunched its Romanian Service after leaving the country a decade ago. The service, known locally as Radio Europa Liberă, was aimed at the dissecting the Russian informational flows in Romania and in Moldova [22]. Moreover, the VOA and its Albanian Service in particular, tries engage and influence people Albania, Kosovo, and 
the Albanian-speaking areas of Macedonia, Serbia, and Montenegro, which are reported to be "vulnerable to internal and external destabilizing forces, including Russian influence" [23].

Macedonia and Serbia are the main countries where the informational projects of both the United States and Russia are clashed. The United States is trying to return the audience after several years of the absence of its informational, educational, and cultural programs. However, coverage problems remain. For example, VOA Albanian TV and digital content reaches only 7.2 percent in Macedonia and VOA Bosnian Service reaches 13.4 population in Macedonia, and the VOA Macedonian Service reaches 19 percent of adults in Macedonia every week that lower than in the other counties of East Europe [23]. $V O A$ Serbian is distributed through 50 national and regional affiliates and online reached 12 percent of adults weekly. In order to eliminate the Russian informational activities, the VOA produced documentary series and general information on Russia's growing influence in Serbia including soft power, media, culture, politics, and Serbia's energy dependency on Russia [23]. The news provides American views on Russian pressure on Montenegro and on the process of Montenegro's accession to NATO. In Montenegro, the VOA is able to dominate the news cycle with national TV and online coverage providing costbenefit analysis of the country's membership in NATO. However, some American experts involved in this activity state that it is extremely difficult to deter Russia throughout the space of her former peripheries since there are many Russian-speaking people, and Russia has a strong influence on the media [24].

The NATO is designated as the main partner for the US public diplomacy projects. The main area of the NATO's contribution is the opening the informational centers that track and publish materials on Russian activities in social media and thus the elaborating messages to attract users in the Russian-language segment of the Internet. Centers such as the EU East Strat-Com Task Force monitor Russian media and generate a quick response to tweets or posts of Russian-speaking bloggers on social networks [24]. Strat-Comm disseminates positive narratives on the United States and its allies and partners and tries to refute Russian narratives and to build resilience among foreign audiences to recognize disinformation.

Moreover, RFE/RL's Ukrainian, Belarusian, Armenia and Georgian services are the main tools to counter the propaganda around Russia. They carry out a wide variety of projects both in the informational area and in the field of training journalists, political consultants, etc. The notion "international broadcasting" has just been enlarged in terms of its functions. The traditional radio and TV channels have been mostly converted into digital platforms that not only inform in one-way, but also engage in dialogue with the public through discussing in comments, posting videos from users and financing a wide variety of projects in the target country.

The innovation in the US international broadcasting was a new type of opinion research through the analysis of the big data implemented by organizations such as the national Democratic Institute or International Republic Institute in European countries in order to define audience that are most vulnerable to Russian campaigns and to respond with messages that that build resilience [25]. For example, in Moldova, the project as the Building Capacity to Produce Alternatives to Russian Television has been accomplished. The project supported independent media in Moldova to bolster local capacity to develop compelling television content. Americans brought Hollywood talent to Moldova to train 
a new generation of screenwriters from Moldova, Latvia, Lithuania, Armenia, and Romania [1]. A Sarajevo-based organization supported by the National Endowment Foundation led Southeast Europe's leading fact-checking and investigative reporting organizations. They track and debunk disinformation and promote alternative news and analysis that challenges illiberal narratives. The Foundation works with groups in Serbia, Montenegro, and North Macedonia to produce attractive content and to identify misleading or false one.

Moreover, the most popular project in this new international broadcasting purposely created for the Russian-speaking population of the post-Soviet space is called as the media literacy. The project was reported to build information consumption critical skills. The IREX, the well-known agency for managing the academic exchanges between the United States and the countries of East Europe and Soviet Union since 1960s, has implemented the project in Ukraine, Moldova, Georgia, Russia, and other countries. The project called Learn to Discern educate the population on how to watch or read news coming from Russia or in Russian [26]. The IREX arranges seminars and conveys the basics of media literacy to a wide range of consumers. The simple handouts and street posters have been created to convey to the audience a distinction between information and propaganda. The most fascinating outcomes are visible in Ukraine, where the project reached several million people through shuttle training and an extensive advertising campaign. The seminars brought together a variety of citizens of Ukraine in terms of their social and professional strata. Pensioners, the youth, activists, teachers, and journalists were selected from 14 regions of the eastern and southern parts in Ukraine. According to the documents, the citizens of western and central part in Ukraine have not been involved in the training as much as they are not regular consumers of Russian-language information. Each participant of the seminars had to transfer their knowledge and skills to another six citizens. Consequently, these seminars, advertisements on TV channels, and large-scale educational materials disseminated in public places covered 20 million viewers, 8 million listeners, 10 million subscribers on the YouTube platform [27]. This project has become a model for other post-Soviet countries. For example, in Moldova, a similar project was implemented by the Deutsche Welle [28]. In Russia, the Current Time joined the project by distributing the See in Both Sides show, the authors of which conduct a comparative analysis of news coming from both Russia and Ukraine [26]. The American experts stated that Embassy public affairs sections support Learn to Discern programs in Ukraine, Serbia and other countries in the region. It was reported that in Ukraine, following intensive media literacy training in 50 secondary schools, theappreciation for professional journalism increased by 12 percent; the number of participants who considered themselves capable of recognizing quality media increased by 36 percent; and those willing to seek out quality reporting increased by 41 percent. Moreover, the Ministry of Education is working with the Department of State to scale up this program to all the schools by 2021 [21]. However, the experts warn that all these projects can have a not very long-term success as far as there are too many people have strong ties with Russia and speak Russian [24].

Consequently, the US international broadcasting has significantly improved its popularity in the post-Soviet Union space including Russia. We have mentioned above that in 2013, only about $0.1-0.3$ percent of Russia's population listened to or watched American broadcasting channels weekly. In 2017, the measured weekly audience of RFE/RL's Russian-language content and Current Time reached 6.4 percent of Russians or nearly 6.6 million people [1]. All the USAGM content on TV, radio and online including mainly 
Current Time, RFE/RL, and VOA was consumed by 7.7 percent of adults each week, or 7.9 million people. [29], [5] If we compare the current percent with the audience percent in the Soviet Union under conditions of heavy jamming, than contemporary figures cannot be depictured as a success of the US public diplomacy. The RFE/RL and VOA reached around 10 percent of audience in the Soviet Union. Some more optimistic sources state about 30-40 percent of audience during the Cold War [30].

Current Time's news reporting in social networks attract audiences aged 15-24. The channel engaged savvy, younger audiences on social, economic and political issues that state media ignores [17]. The primary target audience is so called Generation $\mathrm{Z}$ that is digital young generation who have largely experienced political life under Russia's current political system. In order to reached them, topics include education (studying in America), new technologies, the future of work, and the Kremlin's manipulation of the media. According to the reports, the Current Time's "impact on the Russian media landscape was on display as recently as February 6, when popular Russian YouTube host Yury Dud' cited a Current Time program about hardship in one Kurile military town to challenge Kremlin propaganda chief Dmitry Kiselyov about his own TV show's avoidance of such coverage" [31]. The interview has registered over 6.7 million views since it was posted to YouTube [31].

The years of 2018 and 2019 witnessed the revival of the popularity of the VOA in social media. From June 2018 to June 2019, the VOA Russian Service website registered an average of 2 million monthly visits and 2.5 million monthly article views. Videos on VOA Russian's digital platforms garnered 147 million views on Facebook and 12.7 million views on YouTube. Facebook is the Service's most active social media outreach platform, receiving about 1 million post engagements daily [17].

Finally, the North Caucasus region, Tatarstan, and Bashkiria were also involved in the international broadcasting. The RFE/RL provides programming in local languages its North Caucasus Language Service and its Tatar-Bashkir Service. The Tatar-Bashkir Service is the only major international news provider in the Tatar and Bashkir languages. The service's primary reporting output is in the Tatar language, which is reported to be critical in the strategy of the United states to contain a Russification launched by the Kremlin as it is perceived by the American establishment.

Digital diplomacy of Russia that, according to American experts, contributed to the victory of Donald Trump, is under the response by such agency as the Global Engagement Center (further, GEC). The GEC created by the Obama Administration in order to deal with the ISIS's propaganda in social media, has currently expanded its functions and is responsible for creating counter-messages against Russian active bloggers. The center accumulates data on the information activity in Russia and elaborates the strategy for American digital diplomacy. National Defense Authorization Acts broadened the GEC's mission to "lead, synchronize, and coordinate efforts to understand and counter foreign state and non-state propaganda and disinformation" [14]. There are nearly 90 personnel who track and respond to Russian digital projects. The new functions have been generously funded by the US Congress. If in 2015 and 2016 Center received about $\$ 5$ million for its activities from the federal budget, then today - about $\$ 80$ million annually until 2024 [19]. A special position - SARMAT or Senior Advisor for Russian Malign Activities and Threat - has been created at GEC for revealing and disparaging the activities of Russian channels, bloggers, and etc. [32]. 
Moreover, and more important, The GEC has established Technology Demonstration Series to convene technological solutions in the fight against disinformation. Since mid-2018, the GEC has hosted more than 20 demos of technologies aimed at removing malign propaganda and disinformation. The Series regularly includes observers from the Department of State and Department of Defense, the USAGM, and European embassies [33]. The informational broadcasting has moved to the application of such new technologies as bot network detection, blockchain-enabled content authentication, and countermessaging automation. Definitely, these technologies would open a new prospective for the digital diplomacy. The international broadcasters will use the improved metrics with real-time monitoring tools allowing content to be quickly adapted and distributed to align with audience interests. The informational broadcasting will be able to identify propaganda technologies; define technological vulnerabilities of disinformation operations; predict adversaries' adaptations to US efforts to counter foreign fake information and provide solutions to the challenges posed by adversarial networks like deepfakes [34]. In 2018, the GEC spent \$40 million specifically for initiatives to counter Russian news including deploying technology to provide early warnings of disinformation; analyzing those foreign audiences that are most susceptible to or targeted by disinformation; developing partnerships with key local messengers to produce content to reach critical audiences; and building the technical skills of civil society organizations, NGOs, and journalists to shed light on the spread of disinformation.

The United States has implemented a new project to deepen understanding of the scope and nature of Russian information across 13 Central and East European countries. The project has built resistance to disinformation in the most vulnerable European societies by increasing direct person-to-person engagement on this issue. The project has enabled the civil society organizations to identify and respond to disinformation in locallyrelevant ways. Online analytics has been integrated in the daily activities of local media and NGOs that provided the GEC with tools and capabilities to understand Russian activities in the European countries. North Macedonia, Bulgaria, other countries received the primary attention. The US government works closely with local social media's influencers and help improve their skills that could effectively counter the Russian informational flows [24]. Consequently, the intergovernmental network of digital diplomacy practitioners is being setting up in East Europe and the Balkans [23].

These digital projects and data-driven public diplomacy has contributed to the policy of revealing some suspicious accounts to Facebook, which are removed ahead of any important political event like elections. This approached was applied in Ukraine during the presidential election in 2019 [21]. In Montenegro, a digital forensic center was supported in order to monitor and analyze disinformation targeted at Montenegrin audiences and to provide related media literacy training. According to the documents, the center's analysis highlighted, for example, evidence of Russian involvement "in a local protest designed to stoke ethnic tensions and added to the Department's understanding of continued Russian aims to destabilize Montenegro" [21].

Among new technologies mentioned above, the artificial intelligence will crucially modify the essence of the international broadcasting. Artificial intelligence tools are reported to provide better insights into audience behavior and trends, detect anomalous behavior, detect misinformation campaigns, fraud detection, and aid content creators. The creation of the so-called chatbot 24/7/365 would replace not only hundreds of employees 
of the departments of digital diplomacy, but also would make impact on the discussions of millions of Internet users in all languages of the world.

The other prospective changes in both informational and digital projects are outlined in the bill on the new sanctions package known as the Defending American Security from Kremlin Aggression Act. The bill was introduced in August 2018, but was postponed and discussed in February 2019 before the Munich Security Conference. The bill has currently passed the Senate and publicly known as the DETER Act. The articles of the bill assure the support of NATO strengthening European unity and new sanctions against Moscow. The second section proposes new reforms of the international broadcasting's institutions to deter Russia and calls "for the establishment of a National Fusion Center to Respond to Hybrid Threats $\langle\ldots\rangle$ to be used in countries vulnerable to Russian malign influence, and closer coordination with allies" [35]. The bill fixes the use of digital platforms and big data analysis to engage effectively the target audience, and cybersecurity policy is proposed to be coordinated with the digital diplomacy in order to disseminate information and remove the adversaries' posts from social networks [17].

Summing up, we can state that during the period of 2017-2019 the US international broadcasting endured new and crucial transformations determined by the national security goals and perceptions of Russia. Russia is the factor that contributed to the crucial revisions in the apparatus, funding, and new technological shifts in the international broadcasting of the United States. The new data driven technologies are introduced to reach so called vulnerable audience, track the fakes, and create effective messages.

\section{Conclusion}

The theories of realism and constructivism allow to reveal both national security imperatives and the perceptions of Russia as a threat and adversary that both define the policy of the international broadcasting. We argue that mostly the discussions about the Russian informational measures, its rising as a digital power, and the findings about possible Russian malign interference have determined the transformations in the American public diplomacy and international broadcasting.

During the period of 2013-2019, The United States has profoundly improved previous the quality of the content and audience reach in the regions of East Europe and post-Soviet space. The United States has managed to return the target audience in Russia making almost forgotten Cold War relics as the VOA and RFE/RL be attractive, dynamic, and digital. During the second administration of Barack Obama, Russia was designated as target, and the international broadcasting conducted the policy of engagement towards the Russian-speaking world attracting the people around the world who understand Russian language.

The revelations on Russia's possible interference in the United States and Europe's election campaigns during the first administration of Donald Trump have revised the previous perception of Russia. Instead of the traditional target for the US international broadcasting Russia has been postured as a threat that requires pursing the policy of deterrence. The policy of deterrence has been culminated in expanding the digital diplomacy of the United States and in exploiting the data-driven methods to erode the Russian informational activities within the national clusters of the Internet and social media in the countries of the Balkan region, East Europe, and former Soviet republics. 
The US informational broadcasting has passed fast, but historic transformation, namely from the strategy referred to the winning of the Russian-speaking audience to the policy of deterrence of Russian influence in its nearest neighboring spaces during 2013-2019. The effectiveness of the new informational broadcasting policy will depend on the skillful exploitation of new technologies in terms of data-driven methods.

\section{References}

1. Budget Justification (2020), The US Agency for Global Media, available at: https://www.usagm.gov/wpcontent/uploads/2019/03/USAGMBudget_FY20_CBJ_3-15-19.pdf (accessed: 21.07.2019).

2. Tsvetkova, N. (2017), Soft Power and Public Diplomacy. Tsvetkova N. (ed.). Russia and the World: Understanding International Relations. Roman \& Littlefield, Lanham, New York, London, pp. 231-251.

3. Hearings on Putin's Invasion of Ukraine and the Propaganda that Threatens Europe. The Senate Foreign Relations Subcommittee on Europe and Regional Security Cooperation, November 3, 2015. Testimony of Conley H, available at: https://www.foreign.senate.gov/imo/media/doc/110315_Conley_Testimony.pdf (accessed: 21.07.2019).

4. Tsvetkova, N. (2019), Russian Digital Diplomacy: A Rising Cyber Soft Power? Velikaya A., Simons G. (eds.). Russia's Public Diplomacy: Evolution and Practice. London, New York, Palgrave Macmillan, pp. 103-117.

5. Performance and Accountability Report (2018), US Agency for Global Media, available at: https:// www.usagm.gov/wp-content/uploads/2018/11/USAGM-FY-2018-PAR-FINAL.pdf (accessed: 21.07.2019).

6. Inspection of US International Broadcasting to Russia (2013), Office of Inspector General, available at: https://oig.state.gov/system/files/217908.pdf (accessed: 21.07.2019).

7. Hearings on Putin's Invasion of Ukraine and the Propaganda that Threatens Europe. The Senate Foreign Relations Subcommittee on Europe and Regional Security Cooperation, November 3, 2015. Testimony of Pomerantsev P., available at: https://www.foreign.senate.gov/imo/media/doc/110315_Pomerantsev_Testimony.pdf (accessed: 21.07.2019).

8. Hearings on Putin's Invasion of Ukraine and the Propaganda that Threatens Europe. The Senate Foreign Relations Committee Subcommittee on Europe and Regional Security Cooperation, November 3, 2015. Testimony of Aron L., available at: https://www.foreign.senate.gov/imo/media/doc/110315_Aron_Testimony.pdf (accessed: 21.07.2019).

9. Consolidated and Further Continuing Appropriations Act, 2016. PL 114-113, available at: https://www. congress.gov (accessed: 21.07.2019).

10. Ukraine Freedom Support Act of 2014. PL 113-272, available at: https://www.congress.gov/113/ plaws/publ272/PLAW-113publ272.pdf (accessed: 21.07.2019).

11. Tsvetkova, N., et al. (2019), Sprawling in Cyberspace: Barack Obama's Legacy in Public Diplomacy and Strategic Communication. Journal of Political Marketing, no. 4 (forthcoming).

12. Congressional Budget Request (2016), Broadcasting Board of Governors, available at: https://www.usagm.gov/wp-content/uploads/2015/03/FY2016Budget_CBJ_Final_WebVersion.pdf (accessed: 21.07.2019).

13. Performance and Accountability Report (2016), Broadcasting Board of Governors, available at: https://www.usagm.gov/wp-content/uploads/2016/11/BBG-FY-2016-PAR-Final.pdf (accessed: 21.07.2019).

14. National Defense Authorization Act, 2017. PL 114-328, available at: https://www.congress.gov/114/ plaws/publ328/PLAW-114publ328.pdf (accessed: 21.07.2019).

15. Consolidated Appropriations Act, 2018. PL 115-141, available at: https://www.congress.gov/115/ plaws/publ141/PLAW-115publ141.pdf (accessed: 21.07.2019).

16. Hearings on Undermining Democracy: Kremlin Tools of Malign Political Influence. The House Committee on Foreign Affairs Subcommittee on Europe, Eurasia, Energy and the Environment, May 21, 2019. Testimony of Doran P., available at: https://docs.house.gov/meetings/FA/FA14/20190521/109537/HHRG116-FA14-Wstate-DoranP-20190521.pdf (accessed: 21.07.2019).

17. Hearings on United States Efforts to Counter Russian Disinformation and Malign Influence. The House Appropriations Subcommittee on State, Foreign Operations, and Related Programs, July 10, 2019. Testimony of Polyakova A., available at: https://docs.house.gov/meetings/AP/AP04/20190710/109748/HHRG-116-AP04Wstate-PolyakovaA-20190710.pdf (accessed: 21.07.2019).

18. Statement of Secretary of State Mike Pompeo. The House Appropriations Committee Subcommittee on State, Foreign Operations, and Related Programs on The FY 2020 Budget, March 27, 2019, available at: https:// docs.house.gov/meetings/AP/AP04/20190327/109146/HHRG-116-AP04-Wstate-PompeoM-20190327. pdf (accessed: 21.07.2019). 
19. Countering America's Adversaries Through Sanctions Act, Public Law 11-44, available at: https://www. congress.gov/115/plaws/publ44/PLAW-115publ44.pdf (accessed: 21.07.2019).

20. Consolidated Appropriations Act, 2019. H.J. Res.31, available at: https://www.congress.gov (accessed: 21.07.2019).

21. Hearings on United States Efforts to Counter Russian Disinformation and Malign Influence. The House Appropriations Subcommittee on State, Foreign Operations, and Related Programs, July 10, 2019. Testimony of Kulikowski J., available at: https://docs.house.gov/meetings/AP/AP04/20190710/109748/HHRG-116-AP04Wstate-KulikowskiJ-20190710.pdf (accessed: 21.07.2019).

22. Romania wakes up to RFE/RL, available at: https://www.usagm.gov/2019/01/31/romania-wakes-upto-rfe-rl/ (accessed: 21.07.2019).

23. Comprehensive Annual Report on Public Diplomacy and International Broadcasting. US Advisory Commission on Public Diplomacy, 2018, available at: https://www.state.gov/wp-content/uploads/2019/05/2018ACPD.pdf (accessed: 21.07.2019).

24. Hearings on Russian Social Media Influence: Understanding Russian Propaganda in Eastern Europe. The Senate Select Committee on Intelligence, 2018, August 1, available at: https://www.intelligence.senate.gov (accessed: 21.07.2019).

25. Hearings on Democracy on Promotion in a Challenging World. The House Committee on Foreign Affairs, June 14, 2018, available at: https://docs.house.gov/meetings/FA/FA00/20180614/108418/HHRG115-FA00-Transcript-20180614.pdf (accessed: 21.07.2019).

26. Learn to Discern. IREX, available at: https://www.irex.org/project/learn-discern (accessed: 21.07.2019).

27. One Goal, Two Approaches: Addressing Disinformation in Eurasia. Panel Discussion. Broadcasting Board of Governors, available at: https://www.bbg.gov (accessed: 21.07.2019).

28. Using Media Literacy to Fight Disinformation. Deutsche Welle, available at: http://www.dw.com/en/ using-media-literacy-to-fight-disinformation/a-19410261 (accessed: 21.07.2019).

29. Hearings on United States Efforts to Counter Russian Disinformation and Malign Influence. House Appropriations Subcommittee on State, Foreign Operations, and Related Programs, July 10, 2019. Testimony of Lansing J, available at: https://docs.house.gov/meetings/AP/AP04/20190710/109748/HHRG-116-AP04Wstate-LansingJ-20190710.pdf (accessed: 21.07.2019).

30. Public Diplomacy in the Middle East and South Asia: Is the message getting through? Hearing Before the Subcommittee on the Middle East and South Asia of the Committee on Foreign Affairs. House of Representatives, $110^{\text {th }}$ Congress, $1^{\text {st }}$ Session. May 16, 2007. GPO, Wash. D.C., 2007.

31. Current Time celebrates two years of impact and growth, 2019, February 12, available at: https://www. usagm.gov/2019/02/12/current-time-celebrates-two-years-of-impact-and-growth/ (accessed: 21.07.2019).

32. Hearings on US - Russia Relations US The Senate Foreign Policy Committee, August 21, 2018, available at: https://www.foreign.senate.gov/hearings/us_russia-relations-082118 (accessed: 21.07.2019).

33. Hearings on United States Efforts to Counter Russian Disinformation and Malign Influence. The House Appropriations Subcommittee on State, Foreign Operations, and Related Programs, July 10, 2019. Testimony of Gabrielle L, available at: https://docs.house.gov/meetings/AP/AP04/20190710/109748/HHRG-116-AP04Wstate-GabrielleL-20190710.pdf (accessed: 21.07.2019).

34. The Global Engagement Center's Technology Engagement Team, available at: www.state.gov/r/gec/ tech/index.htm (accessed: 21.07.2019).

35. Defending American Security from Kremlin Aggression Act. S.3336, available at: https://www.congress.gov/bill/115th-congress/senate-bill/3336/text (accessed: 21.07.2019).

Received: September 3, 2019

Accepted: October 3, 2019

Author's information:

Natalia A. Tsvetkova — Doctor of Science (History), Professor; n.tsvetkova@spbu.ru 